\title{
Relationship between vitamin intake and total antioxidant capacity in elderly adults
}

\author{
Myriam Lucia Ojeda Arredondo, ${ }^{1, *}$, Magda Catalina Pinilla Betancourt ${ }^{1}$, \\ Martha Lucia Borrero Yoshida ${ }^{1}$, Gonzalo Sequeda ${ }^{2}$, Vivian Maritza Castro Herrera ${ }^{1}$, \\ Ángela Sofía García Vega ${ }^{1}$, Juanita Carolina Rodríguez Rodríguez ${ }^{1}$, \\ Ofelia Diez ${ }^{3}$, Paolo Lucci ${ }^{4}$
}

\begin{abstract}
Edited by
Juan Carlos Salcedo-Reyes

(salcedo.juan@javeriana.edu.co)

1. Pontificia Universidad Javeriana,

Faculty of Sciences, Department of

Nutrition and Biochemistry, Grupo de

Nutrición, Alimentación y Salud, Bogotá,

Colombia.

2. Pontificia Universidad Javeriana,

Science Faculty Department of

Chemistry Bogotá, Colombia.

3. Pontificia Universidad Javeriana,

Science Faculty Department of

Microbiology, Bogotá, Colombia.

4. University of Udine, Dipartimento di Scienze degli Alimenti Via Sondrio 2/A, 33100 Udine, Italy.

*mojeda@javeriana.edu.co

Received: 02-09-2015

Accepted: 03-06-2016

Published on line: 21-06-2016

Citation: Ojeda ML, Pinilla MC, Borrero ML, Sequeda G, Castro VM, García AS, Rodríguez JC, Diez O, Lucci P. Relationship between vitamin intake and total antioxidant capacity in elderly adults,

Universitas Scientiarum, 21 (2): 167-177, 2016.

doi: 10.11144/Javeriana.SC21-2.rbvi

Funding:

Pontificia Universidad Javeriana
\end{abstract}

Electronic supplementary material: $\mathrm{N} / \mathrm{A}$

OPEN ACCESS

\begin{abstract}
The consumption of foods high in natural antioxidants, like fruits and vegetables, is associated with a lower risk of oxidative stress-related diseases. The aim of this study was to establish the relationship between the plasma antioxidant capacity in adults over fifty and their intake of vitamin A, C, and E. We evaluated 118 24-hour recalls of intake of foods. The intake of vitamin A, C, and $\mathrm{E}$ was quantified using food composition tables. We quantified plasma phenols using the Folin-Ciocalteu method. The antioxidant capacity was determined using the Trolox Equivalent Antioxidant Capacity (TEAC) and Oxygen Radical Absorption Capacity (ORAC) methods. Correlation analyses were performed between the studied variables and a positive correlation was found in most cases. However, none of the correlations was statistically significant. In all cases p-value was $>0.05$. The quantification of nutrient intake is not an adequate predictor of plasma antioxidant capacity in individuals over fifty.
\end{abstract}

Keywords: Oxidative stress; free radicals; phenolic compounds; Carotene; Tocopherol.

\section{Introduction}

Current scientific evidence indicates that oxidative stress is directly involved in the onset and development of chronic, non-communicable diseases such as cardiovascular disease, rheumatoid arthritis, and some neurodegenerative diseases like Alzheimer's and Parkinson's (Luc \& Fruchart 1991, Darlington et al. 2001, Pulido et al. 2005, Sharma et al. 2008). The oxidative stress involved in the pathogenesis of these diseases is a consequence of the increased production of free radicals (FR) and the inability of the human body's antioxidant systems to counteract the negative effects (Rao et al. 2011) leading to tissue damage, a product of the oxidative alteration of macromolecules such as lipids and DNA (Diplock et al. 1998). 
These antioxidants systems are made up of both endogenous molecules in the body such as superoxide dismutase and glutathione reductase enzymes, bilirubin and uric acid (Sen et al. 2010), and substances of exogenous origin present in foods such as vitamins, minerals, and polyphenols (Diplock et al. 1998). Together, these substances are the defense mechanisms against FR attacks.

Among the different antioxidants of exogenous origin is vitamin A. This vitamin was first labeled as a suppressor of the effect of linoleic acid on the oxidation processes (Monaghan et al. 1932). Currently, vitamin A and carotenoids are known for their antioxidant activity based on their ability to interact with radicals and prevent lipid peroxidation of the cell (Palace et al. 1999). Ascorbic acid is both a reducing agent that loses an electron to generate a relatively stable radical (Gil 2010) and a regenerator of vitamin $\mathrm{E}$ that after oxidation produces tocopherol (Jayachandran et al. 1996). Tocopherol is a primary lipophilic antioxidant that inactivates peroxyl radicals through the direct transfer of a hydrogen atom (Niki 2014) and protects tissue lipids from the damage produced by free radicals (Febles et al. 2009).

Various studies suggest that increased consumption of fruits and vegetables reduces the risk of oxidative stress-related diseases, attributing this benefit to the high content of antioxidant compounds in these foods (Steinmetz et al. 1996, Knekt et al. 2002). Moreover, an increase in the consumption of foods rich in antioxidants such as vitamins and polyphenols increases the total antioxidant capacity (TAC) (Vieira et al. 2012) and reflects the joint action of the various individual antioxidants in plasma (Ghiselli et al. 2000).

While recognizing the importance of antioxidant compounds of exogenous origin and their function against the harmful effects of FR, the objective of this study is to determine whether taking vitamins A, C, and $\mathrm{E}$ is associated with antioxidant levels in a group of individuals over fifty.

\section{Materials and methods}

Population

The population of this study was 118 adults over the age of 50 (108 women and ten men) and all participate named Healthy and Active Individuals of the Departmental Institute of Recreation and Sports Seniors Program (DIRS) located in Usme, in the city of Bogotá, Colombia. The data of the participant were obtained in the initial phases of the "Effects of the Consumption of Hybrid Palm Oil and Extra Virgin Olive Oil on Emerging and Traditional Cardiovascular Risk Factors" study (Mozzon et al. 2013, Lucci et al. 2016). This study was conducted in compliance with the guidelines of the Declaration of Helsinki. The institutional ethics committee of the Universidad Pontificia Javeriana in Bogotá approved all of the procedures involving human subjects (Law No. 11, 21-06- 2011).

\section{Consumption Evaluation}

To determine the consumption of vitamins A, C, and E, each of the study participants had two 24-hour recalls and a food frequency recall obtained from the previously mentioned research study in which all the participants partook.

For this study, we analyzed the 24-hour recalls, which were obtained on the same day that blood was drawn from the participants to be subsequently evaluated for plasma antioxidant capacity. 
Food intake information was obtained from each participant's 24-hour recall sheet and vitamin $\mathrm{A}$ and $\mathrm{C}$ consumption was determined using food composition tables from the Nutritional Care Center in Medellin, Colombia and the Colombian Institute of Family Welfare. Vitamin A was reported in retinol equivalents and vitamin C in $\mathrm{mg}$. Vitamin $\mathrm{E}$ was also reported in $\mathrm{mg}$; however, its analysis considered the reported values in the USDA National Nutrient Data Base for Standard Reference, bearing in mind that the values in this database, for the same food, was similar (90-110\%) to the energy and nutrient supply values reported in the Medellin Nutritional Care Center's food composition table.

\section{Plasma antioxidant capacity}

Blood samples from each study participant were obtained on an empty stomach to determine the antioxidant capacity and the plasma concentration of phenols. These procedures were performed as a part of the previously mentioned research study in which each of the participants participated.

The methods used to obtain antioxidant levels were ORAC (Oxygen radical absorbance capacity) (Cao et al. 1995) and TEAC (Trolox Equivalent Antioxidant Capacity) (Miller et al. 1993). Plasma phenol quantification was achieved employing the Folin-Ciocalteu (Singleton et al. 1965) methodology.

Using the data obtained in the initial phases of the "Effects of the Consumption of Hybrid Palm Oil and Extra Virgin Olive Oil on Emerging and Traditional Cardiovascular Risk Factors" study, we obtained the antioxidant capacity values by TEAC for 118 participants. Using ORAC, we obtained values for 114 participants and quantified phenols for 117 individuals (Ojeda et al. 2016).

Statistic analysis

The tabulation of information was completed using Excel 2007. The statistical program IBM SPSS Statistics 21 was used to analyze the variables of vitamin A, C, and $\mathrm{E}$ antioxidant levels and the concentration of phenols in plasma.

Normal distribution was checked using the Kolmogorov-Smirnov test. Correlation analysis was performed using the Spearman test for variables that did not meet the assumptions of normality and the Pearson test when both variables had a normal distribution. The value of $\mathrm{p}<0.05$ was considered statistically significant.

\section{Results}

\section{Quantitative analysis of vitamin consumption}

In the end, 118 24-hour recalls were evaluated. According to the results, the average consumption of both vitamin $\mathrm{A}$ and $\mathrm{C}$ met the recommendations stipulated in the Dietary Reference Intakes (DRI) tables for both men and women. However, in neither group did the consumption of vitamin $\mathrm{E}$ reach the minimum recommended levels.

\section{Antioxidant capabilities and plasma phenols quantification}

Table 1 shows the means for the different measurement techniques used to gauge antioxidant capacity and quantify plasma concentrations of phenols. Note that 118 results were obtained using the TEAC method, 114 using ORAC, and 117 with RCF. 
Table 1. Average plasma antioxidant capacity in the study population

\begin{tabular}{cccc}
\hline Method & $\mathbf{n}$ & Media & SD \\
\hline $\begin{array}{c}\text { TEAC } \\
\text { mmol equivalent trolox/L of plasma } \\
\text { ORAC }\end{array}$ & 118 & 1.85 & 0.34 \\
$\begin{array}{c}\boldsymbol{\mu} \mathbf{M} \text { de trolox } / \mathbf{L} \text { of plasma } \\
\text { FOLIN }\end{array}$ & 114 & 2102.6 & 607.47 \\
$\begin{array}{c}\text { mg of gallic acid/L of plasma } \\
\text { m }\end{array}$ & 117 & 362.39 & 41.07 \\
\hline
\end{tabular}

Vitamin consumption and antioxidant capacity using the TEAC method

Table 2 shows a positive correlation between the consumption of vitamin A, C, and $\mathrm{E}$ and the antioxidant capacity of plasma measured using the TEAC method. However, the value of $\mathrm{p}$ for the three tests was greater than 0.05 ; these results are not statistically significant.

Table 2. Correlation between the consumption of vitamins A, C and $\mathrm{E}$ and antioxidant levels in plasma by the TEAC method. ${ }^{*}$ Spearman, ${ }^{* *}$ Pearson.

\begin{tabular}{cc}
\hline VITAMIN & $\begin{array}{c}\text { CORRELATION COEFFICIENT } \\
\mathbf{n}=118\end{array}$ \\
\hline Vitamin $\mathbf{A}^{*}$ & 0.032 \\
Vitamin $^{*}$ & 0.162 \\
Vitamin $\mathbf{E}^{* *}$ & 0.061 \\
\hline
\end{tabular}

Vitamin consumption and antioxidant capacity using the ORAC method

Table 3 shows a positive correlation between the consumption of vitamin A and C and antioxidant capacity measured using the ORAC method. A negative correlation is evidenced by the consumption of vitamin E. However, none of the results displayed was statistically significant.

Table 3. Correlation between the consumption of vitamins A, C and $\mathrm{E}$ and antioxidant levels in plasma measured by the ORAC method. ${ }^{*}$ Spearman, ${ }^{*}$ Pearson.

\begin{tabular}{cc}
\hline VITAMIN & $\begin{array}{c}\text { CORRELATION COEFFICIENT } \\
\mathbf{n}=114\end{array}$ \\
\hline Vitamin $\mathbf{A}^{*}$ & 0.086 \\
Vitamin $\mathbf{C}^{*}$ & 0.048 \\
Vitamin $\mathbf{E}^{* *}$ & -0.057 \\
\hline
\end{tabular}


Vitamin consumption and quantification of phenolic content

According to the results presented in Table 4, there is a positive correlation between the consumption of vitamin $\mathrm{A}$ and $\mathrm{E}$ and the quantification of phenols in plasma measured by RFC. However, the p-value for both tests was $>0.05$ yielding statistically non-significant results. As for vitamin $\mathrm{C}$, there was no correlation observed with plasma concentration of phenol levels.

Table 4. Correlation between the consumption of vitamins A, C and E and plasma concentrations of phenols measured by the RFC. ${ }^{*}$ Spearman, ${ }^{* *}$ Pearson.

\begin{tabular}{cc}
\hline VITAMIN & $\begin{array}{c}\text { CORRELATION COEFFICIENT } \\
\mathbf{n}=117\end{array}$ \\
Vitamin $\mathbf{A}^{*}$ & 0.076 \\
Vitamin $\mathrm{C}^{*}$ & 0 \\
Vitamin $\mathrm{E}^{* *}$ & 0.038 \\
\hline
\end{tabular}

\section{Discussion}

Currently, efforts to understand the ability of free radicals to directly influence the development of different pathological processes, especially those related to chronic, non-communicable diseases such as cardiovascular disease and neurodegenerative diseases, have targeted a specific line of research aimed at finding mechanisms that protect the body from oxidative damage (Luc \& Fruchart 1991, Gale et al. 2001).

Epidemiological studies suggest that increased consumption of antioxidantrich foods, such as fruits and vegetables, directly and positively influences plasma antioxidant capacity, while recognizing that this concept comprises the synergistic action of all antioxidants in body fluids, whether endogenous or exogenous (Wang et al. 2012, Kolomvotsou et al. 2012).

Using the ORAC method in young and senior adults, experimental studies have determined that increasing the consumption of fruits and vegetables to 5-10 servings per day for 15 days, positively influences the levels of antioxidant capacity (Cao et al. 1998). These results show that by eating certain foods, the body benefits from additional antioxidants of exogenous origin.

The results obtained in this study found that the average intake of vitamin E in seniors over 50 years do not meet the recommendations stipulated in the DRI, for both men and women. A negative correlation was found between the intake of vitamin $\mathrm{E}$ relative and the plasma antioxidant capacity measured by the ORAC method. This result is comparable to a previous study by Wang et al (2012) that also reported a negative correlation when analyzing antioxidant capacity versus Vitamin E consumption, and notably, a strong association between plasma $\alpha$-tocopherol levels and the antioxidant capacity of plasma. The previous underscores not only the importance of consuming a nutrient, but also the importance of complying with 
the recommendation (Recommended Dietary Allowance: $15 \mathrm{mg}$ vitamin E/day) to achieve optimal metabolism. On the other hand, the interaction between different antioxidants contained in food or diet must also be considered. At the time of consumption, a synergy may or may not exist thus influencing the effect of vitamin $\mathrm{C}$ on alphatocopherol (vitamin E) absorption (Pineda et al. 1999).

Using the TEAC method, we found a statistically non-significant positive correlation between the consumption of $\alpha$-Tocopherol and antioxidant levels. This result is consistent with a study by Talegawkar et al (2009) that found no significant association between the two. However, the mentioned study stresses that large intakes of vitamin $\mathrm{E}$ increased performance in antioxidant capacity; this behavior was observed in individuals in the study group averaging a consumption of $285 \mathrm{mg} / \mathrm{d}$ of $\alpha$-Tocoferol.

The low correlation reported between antioxidant capacity levels and the consumption of vitamin $\mathrm{E}$ could be attributed to an inadequate intake of this nutrient, which was lower than the recommended amounts according to age and sex; this leads to a long-term impairment in antioxidant capacity.

A very low correlation was observed between vitamin $C$ consumption and the levels of antioxidant capacity obtained both by TEAC and ORAC. This result is contrary to what is stated in a study by Talegawkar et al (2009) in which higher levels of antioxidant capacity were observed as the consumption of vitamin $\mathrm{C}$ increased (Talegawkar et al. 2009).

However, previous studies show that the increase in antioxidant capacity after consuming strawberries and spinach is attributed only in $8-14 \%$ to vitamin $\mathrm{C}$ content in these foods. Therefore, it is various phenolic compounds that are primarily responsible for the increased plasma antioxidant capacity and not vitamin C (Cao et al. 1998).

With regard to vitamin A, a positive correlation was observed between the consumption of this nutrient and the antioxidant capacity measured by TEAC and ORAC. However, none of the results were statistically significant. This result differs from the findings of an earlier study by Meydani et al (1994) that reported an increased antioxidant capacity in elderly women after receiving $\beta$-carotene supplements. It's worth noting that the present study evaluated the antioxidant capacity based on the intake of vitamin A product of a daily diet and not accompanied by supplements as in the aforementioned study.

Lastly, we observed a non-statistically significant positive correlation between vitamin $\mathrm{A}$ and $\mathrm{E}$ and the results obtained using the RFC methodology. Additionally, the null relationship between these results and the levels of vitamin $\mathrm{C}$ consumed. This finding is easily explained by the nature of the method used. This methodology is exclusively for the measurement of phenolic compounds, which are essential in determining antioxidant capacity; however, none of the nutrients analyzed are substances of phenolic nature (Miniati 2007).

The intake of vitamin A, C, and E did not show a statistically significant correlation with regard to the levels of plasma antioxidant capacity as observed in the present study. This result is consistent with previous studies as published by Pellegrini et al. 
in 2000 in which it was concluded that after eating tomatoes, a food high in lycopene, the antioxidant capacity of plasma of these individuals was not affected. Likewise in another study, Li L et al. (2010) concluded that after giving lutein supplementation to healthy adults between 50 and 70 years, these showed no change in markers of antioxidant activity and lipid peroxidation, indicating that increase of antioxidant concentrations in a healthful diet does not affect the levels of plasma antioxidant capacity in normal healthy subjects when the amounts of antioxidants already are adequate. These helps support the claim that intake levels not directly related to the levels of antioxidant capacity in healthy adults.

We can conclude that quantifying intake is perhaps not an adequate predictor of levels of plasma antioxidant capacity; this does not however mean that it has no influence. It is important to emphasize that existing literature reports a positive relationship between the antioxidant capacity and plasma levels of nutrients (Wang et al. 2012, Meydani et al. 1994) as well as between their intake and their plasma concentration levels (Mitmesser et al. 2000). Thus, the consumption is an adequate predictor of nutrient serum levels, which, in turn, are a reflection of the antioxidant capacity of plasma, when the vitamins (A, E and $\mathrm{C}$ ) are measured directly in plasma.

\section{Acknowledgment}

The authors appreciate the financial support provided by the Pontificia Universidad Javeriana for this study.

\section{Conflicts of Interest}

The authors declare no conflict of interest.

\section{References}

Cao G, Booth S, Sadowski, Prior R. Increases in human plasma antioxidant capacity after consumption of controlled diets high in fruit and vegetables, The American Journal of Clinical Nutrition, 68:1081-1087, 1998.

Retrieved from: http://ajcn.nutrition.org/content/68/5/1081.full.pdf

Cao G, Russell R, Lischner N, Prior R. Serum antioxidant capacity is increased by consumption of strawberries, spinach, red wine or vitamin C in elderly women, The Journal of Nutrition, 128(12): 2383-2390, 1998.

Retrieved from: http://jn.nutrition.org/content/128/12/2383.full

Cao G, Verdon CP, Wu AH, Wang H, Prior RL. Automated assay of oxygen radical absorbance capacity with the COBAS FARA II, Clinical Chemistry, 41(12):1738-1744, 1995.

Retrieved from: http://www.clinchem.org/content/41/12/1738.long

Darlington L, Stone T. Antioxidants and fatty acids in the amelioration of rheumatoid arthritis and related disorders, British Journal of Nutrition, 85:251-269, 2001. doi: 10.1079/BJN2000239

Diplock A, Charleux J, Crozier-Willi G, Kok F, Rice-Evans C, Roberfroid M, Stahl W, ViñaRibes J. Functional food science and defense against reactive oxidative species, British Journal of Nutrition, 80(1):77-112, 1998.

Febles C, Soto C, Saldaña A, García B. Funciones de la vitamina E. Actualización, Revista Cubana de Estomatología, 39(1):28-32, 2002. 
Gale C, Ashurst H, Powers H, Martyn C. Antioxidant vitamin status and carotid atherosclerosis in the elderly, The American Journal of Clinical Nutrition, 74:402-408, 2001.

Retrieved from: http://ajcn.nutrition.org/content/74/3/402.long

Ghiselli A, Serafini M, Natella F, Scaccini C. Total Antioxidant capacity as a tool to assess redox status: critical view and experimental data. Free Radical Biology \& Medicine 29(11):1106-1114, 2000.

doi: 10.1016/S0891-5849(00)00394-4

Gil A. Tratado de Nutrición: Bases fisiológicas y bioquímicas de la nutrición. Segunda Edición. Editorial Médica Panamericana. Madrid, España, 2010.

Jayachandran M, Jayanthi B, Sundaravadivel B, Panneerselvam C. Status of lipids, lipid peroxidation, and antioxidant systems with vitamin $\mathrm{C}$ supplementation during aging in rats, The Journal of Nutrition Biochemistry, 7(5):270-275, 1996.

Retrieved from: http://dx.doi.org/10.1016/0955-2863(96)00027-7

Knekt P, Kumpulainen J, Jârvinen R, Rissanen H, Heliôvaara M, Reunanen A, Hakulinen T, Aromaa A. Flavonoid intake and risk of chronic diseases, The American Journal of Clinical Nutrition, 76:560-568, 2002.

Retrieved from: http://ajcn.nutrition.org/content/76/3/560.full.pdf + html

Kolomvotsou A, Rallidis L, Mountzouris K, Lekakis J, Koutelidakis A, Efstathiou S, NanaAnastasiou M, Zampelas A. Adherence to Mediterranean diet and close dietetic supervision increase total dietary antioxidant intake and plasma antioxidant capacity in subjects with abdominal obesity. European Journal of Nutrition 52(1):37-48, 2012.

doi: 10.1007/s00394-011-0283-3

Li L, Chen CY, Aldini G, Johnson EJ, Rasmussen H, Yoshida Y, Niki E, Blumberg JB, Russell RM, Yeum KJ. Supplementation with lutein or lutein plus green tea extracts does not change oxidative stress in adequately nourished older adults, The Journal of Nutrition Biochemistry, 21:544-549, 2010.

doi: 10.1016/j.jnutbio.2009.03.002

Luc G, Fruchart J. Oxidation of lipoproteins and atherosclerosis, The American Journal of Clinical Nutrition, 53:206-209, 1991.

Retrieved from: http://ajcn.nutrition.org/content/53/1/206S.abstract

Lucci P, Borrero M, Ruiz A, Pacetti D, Frega NG, Diez O, Ojeda M, Gagliardi R, Parra L, Angel M. Palm oil and cardiovascular disease: a randomized trial of the effects of hybrid palm oil supplementation on human plasma lipid patterns, Food \& Function, 7:347-54, 2016. doi: $10.1039 / \mathrm{c} 5$ fo01083g

Meydani M, Martin A, Mercado J, Gong J, Blumberg J, Russell R (1994) B-Carotene supplementation increases antioxidant capacity of plasma in older women. The journal of nutrition 124(12):2739-2403

Miller N, Rice-Evans C, Davies M, Gopinathan V, Milner A. A novel method for measuring antioxidant capacity and its application to monitoring antioxidant status in premature neonates, Clinical Science 84:407-412, 1993.

doi: $10.1042 / \operatorname{cs} 0840407$

Miniati E. Assessment of phenolic compounds in biological samples, Ann Ist Super Sanitá 43(4): 362-368, 2007.

Retrieved from: http://www.iss.it/publ/anna/2007/4/434362.pdf

Mitmesser S, Giraud D, Driskell J. Dietary and plasma levels of carotenoids, vitamin E, and vitamin $\mathrm{C}$ in a group of young and middle-aged nonsupplemented women and men, Nutrition Research, 20(11):1537-1546, 2000.

doi: 10.1016/S0271-5317(00)00238-4

Monaghan B, Schmitt F. The effects of carotene and of vitamin A on the oxidation of linoleic acid, The Journal of Biological Chemistry, 96:387-395, 1932.

Retrieved from: http://www.jbc.org/content/96/2/387.full.pdf 
Mozzon M, Pacetti D, Lucci P, Balzano M. Frega, NG. Crude palm oil from interspecific hybrid Elaeis oleifera $\times$ Elaeis guineensis: fatty acid regiodistribution and molecular species of glycerides, Food Chemistry, 141:245-52, 2013.

doi: 10.1016/j.foodchem.2013.03.016

Ojeda M, Borrero M, Sequeda G, Diez O, Castro V, Garcia A, Ruiz A, Pacetti D, Frega NG, Gagliardi R, Lucci P. Hybrid palm oil (Elaeis oleifera $\times$ Elaeis guineensis) supplementation improves plasma antioxidant capacity in humans, European Journal of Lipid Science and Technology, Accepted Manuscript, 2016.

doi: $10.1002 /$ ejlt.201600070

Niki E. Role of vitamin E as a lipid-soluble peroxyl radical scavenger: in vitro and in vivo evidence, Free Radical Biology \& Medicine, 66:3-12 , 2014.

doi: 10.1016/j.freeradbiomed.2013.03.022

Palace V, Khaper N, Qin Q, Singal P. Antioxidant potentials of vitamin A and carotenoids and their relevance to heart disease. Free Radical Biology \& Medicine 26(5/6):746-761, 1999. doi: 10.1016/S0891-5849(98)00266-4

Pellegrini N, Riso P, \& Porrini M (2000) Tomato Consumption Does Not Affect the Total Antioxidant Capacity of Plasma. Nutrition 16, 268-271.

doi: http://dx.doi.org/10.1016/S0899-9007(99)00305-6

Pineda AD, Salucci M, Lázano R, Madani G, Ferro-Luzzi A. Capacidad antioxidante y potencial de sinergismo entre los principales constituyentes antioxidantes de algunos alimentos, Revista Cubana de Alimentos y Nutrición, 13(2): 104 - 111, 1999.

Pulido R, Jiménez-Escrig A, Orensanz L, Saura-Calixto F, Jiménez-Escrig A. Study of plasma antioxidant status in Alzheimer`s disease. European Journal of Neurology 12:531-535, 2005. doi: 10.1111/j.1468-1331.2005.01000.x

Rao S, Kalva S, Yerramilli A, Mamidi S. Free radicals and tissue damage: role of antioxidants, Free Radicals and Antioxidants, 4(1):2-7, 2011

doi: 10.5530/ax.2011.4.2

Sen S, Chakraborty R, Sridhar C, Reddy Y, De B. Free radicals, antioxidants, diseases and phytomedicines: current status and future prospect, International Journal of Pharmacentical Sciences Review and Research, 31(1):91-100, 2010.

http://www.globalresearchonline.net/journalcontents/volume3issue1/Article\%20021.pdf

Sharma A, Kau P, Kumar B, Prabhakar S, Gill, K.D. Plasma lipid peroxidation and antioxidant status of Parkinson`s disease patients in the Indian population, Parkinsonism and Related Disorders, 14:52-57, 2008.

doi: 10.1016/j.parkreldis.2007.06.009

Singleton V, Rossi J. Colorimetry of total phenolics with Phosphomolybdic-phosphotungstic acid reagents, American Journal Enologist and Viticulture, 16:144-158, 1965.

Retrieved from: http://www.ajevonline.org/content/16/3/144

Steinmetz K., Potter J. Vegetables, fruit, and cancer prevention: A review, Journal of the American Dietetic Association, 96:1027-1039, 1996.

doi: http://dx.doi.org/10.1016/S0002-8223(96)00273-8

Talegawkar S, Beretta G, Yeum K, Johnson E, Carithers T, Taylor Jr H, Russell R, Tucker K. Total antioxidant performance is associated with diet and serum antioxidants in participants of the diet and physical activity substudy of the Jackson Heart Study, The Journal of Nutrition, 139:1964-1971, 2009. doi: $10.3945 /$ jn.109.107870

Vieira F, Di Pietro P, Silva E, Borges G, Nunes E, Fett R. Improvement of serum antioxidant status in humans after the acute intake of apple juices, Nutrition Research, 32:229-232, 2012. doi: 10.1016/j.nutres.2011.12.008

Wang Y, Yang M, Lee S, Davis C, Koo S, Chun O. Dietary total antioxidant capacity is associated with diet and plasma antioxidant status in healthy young adults, Journal of the Academy of Nutrition and Dietetics, 112(10):1626-1635, 2012.

doi: 10.1016/j.jand.2012.06.007 
Relación entre ingesta de vitaminas y capacidad atnioxidante total en adultos mayores

Resumen. El consumo de alimentos ricos en antioxidantes naturales, como frutas y vegetales, está asociado con un menor riesgo de enfermedades relacionadas con el estrés oxidativo. El objetivo de este trabajo fue establecer la relación entre capacidad antioxidante del plasma en adultos mayores de cincuenta años y su consumo de vitamina A, C y E. Se evaluaron 118 recordatorios de ingesta de alimentos de 24 horas. La ingesta de vitamina A, C y E fue cuantificada usando tablas de composición de alimentos. Se cuantificaron los fenoles en plasma usando el método Folin-Ciocalteu, y la capacidad antioxidante se determinó con base en los métodos de Capacidad Antioxidante Equivalente a Trolox (TEAC) y de Capacidad de Absorción de Radicales de Oxígeno (ORAC). Se realizaron análisis de correlación entre las variables estudiadas y se encontró una correlación positiva en la mayoría de los casos. Sin embargo, ninguna de las correlaciones resultó estadísticamente significativa. En todos los casos, $p>0.05$. La cuantificación de ingesta de nutrientes no es un predictor adecuado de la capacidad antioxidante del plasma en adultos mayores de 50 años.

Palabras clave: estrés oxidativo; radicales libres; compuestos fenólicos; caroteno; tocoferol.

Relaçáo entre a ingestão de vitaminas e a capacidade antioxidante total em idosos

Resumo. O consumo de alimentos ricos em antioxidantes naturais, como frutas e vegetais, é associado a um baixo risco de doenças relacionadas ao estresse oxidativo. O objetivo do trabalho foi determinar a relação entre a capacidade antioxidante plasmática em adultos acima de cinquenta anos e sua ingestão de vitamina A, C e E. Foram avaliados 118 lembretes de consumo de alimentos de 24 horas. A ingestão de vitamina A, C e E foi quantificada usando tabelas de composição de alimentos. Foram quantificados fenóis plasmáticos usando método Folin-Ciocalteu baseado na base de dados de um estúdio prévio e obtivemos a capacidade antioxidante utilizando os métodos de Capacidade Antioxidante Equivalente de Trolox (TEAC) e Capacidade de Absorção de Radical Oxigênio (ORAC). Análises de correlação foram realizadas para cada variável estudada e uma correlação positiva foi obtida na maioria dos casos. Entretanto, nenhuma das relações mostrou resultados estatisticamente significativos. Em todos os casos, o valor de $p>0,05$. A quantificação da ingestão de nutrientes não é um preditor adequado da capacidade antioxidante plasmática em indivíduos acima de cinquenta anos.

Palavras-chave: estresse oxidativo; radicais livres; compostos fenólicos; caroteno; tocoferol.

Myriam Lucia Ojeda Arredondo

Nutritionist-Dietitian, professor of human nutrition area in the career of Nutrition and Dietetics at the Sciences Faculty of the Pontificia Universidad Javeriana, Master and $\mathrm{PhD}$ in Biological Sciences in some University. Member of the research group Food, Nutrition and Health. His work and research have been focused on the risk factors of cardiovascular disease and clinical nutrition in adult individuals.

Magda Pinilla Catalina Betancourt

Nutritionist-Dietitian of the Pontificia Universidad Javeriana. Currently analyst special project on human health and nutrition - Cenipalma. 
Martha Lucia Borrero Yoshida

Nutritionist-Dietitian, Master in Health Administration, professor of feeding area in the career of Nutrition and Dietetics at the Sciences Faculty of the Pontificia Universidad Javeriana.

\section{Gonzalo Sequeda}

Chemicist, ISO 17025 Auditor, Master in Biological Sciences and PhD Candidate in Pharmaceutical Sciences of the National University of Colombia. Professor of Chemistry at the Sciences Faculty of the Pontificia Universidad Javeriana. Working in areas of Analytical Chemistry, Food Chemistry and Pharmacognosy \& Phytochemistry. Currently running projects related to the search of extracts, fractions and compounds with antioxidant, antimicrobial and remineralizing tooth enamel activity, plant, mineral and synthetic.

\section{Vivian Herrera Castro Maritza}

Nutritionist-Dietitian, Masters in Physical Activity and Health, with emphasis on biological sciences. Currently cPHD Human Development and Health - Inmunonutrition and physical activity at the University of Southampton.

\section{Angela Garcia Vega Sofia}

Biologist and Nutritionist-Dietitian of the Pontificia Universidad Javeriana. Currently Colciencias young researcher of the research group Biochemistry Computational and Bioinformatics, Sciences Faculty, Nutrition and Biochemistry Department, Pontificia Universidad Javeriana.

\section{Juanita Carolina Rodríguez Rodríguez}

Biologist of the Pontificia Universidad Javeriana. Young researcher of Colciencias at the Department of Nutrition and Biochemistry at Javeriana University.. Currently finishing the Master's in Synthetic Biology and Master's in High-throughput Biotechnology at the École Supérieure de Biotechnologie (France).

\section{Ofelia Diez Arbeláez}

Bacteriologist, Master in Biological Sciences at the Javeriana University. Professor of microbiology area at the Sciences Faculty of the Pontificia Universidad Javeriana and extensive experience in clinical laboratory of the same University.

\section{Paolo Lucci}

Undergraduate Agricultural Science and Technology, Master of Biotecnologíay, PhD in Food Chemistry at the Universita Politecnica delle Marche (Italy) and Postdoctoral in Analytical Chemistry with Polyintell (France) and the University of Barcelona (Spain). Currently professor of the Agri-Food, Animal and Environmental Sciences Department at the Udine University, Udine, Italy. 